\title{
Molecular view to the effect of centaury oil on wound healing
}

\section{Kantaron yağının yara îilleşmesi üzerine olan etkisine moleküler bakış}

Zehra Dilşad Çoban ${ }^{1}$, Mustafa Yener ${ }^{2}$, Ahmet Samed Benli², Kerim Amanov², Ertan Altaylı ${ }^{1}$, Halide Demir ${ }^{1}$, Özgüir Kıllıçarslan ${ }^{1}$, Emre Çavana ${ }^{3}$, Şefik Güiran ${ }^{1}$

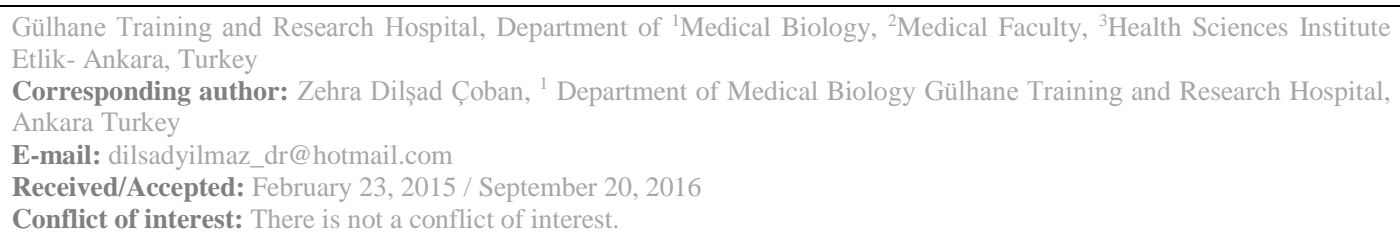

\begin{abstract}
SUMMARY
Centaury oil (the extract of Hypericum perforatum obtained with olive oil) is traditionally used for the treatment of wounds in Turkey. Centaury oil has analgesic and anti-infectious properties beside wound healing effect. There are many studies about the positive effect of this extract on wound healing in literature. But there is no mention about the animal studies that show which pathways are involved in. In our study the effect of centaury oil in early stages (first 7 days) and late stages (second 7 days) of wound healing was showed on the mice (mus. musculus) by creating sterile sutures on their back. Due to our results, centaury oil has positive effects on the surface of the wounds in early stages but has no effect on late stages. This information is explained as centaury oil can be useful if it is used in the first week of the wound. In addition, the gene expression profiles of $V E G F A, V E G F B$, $V E G F C, P D G F B$ and $F G F 2$ genes which have roles in wound healing via angiogenesis, were studied by RT-PCR method. As a result, the gene expression levels of VEGFA, VEGFB, VEGFC and $F G F 2$ were increased in early stages of wound healing but only VEGFA gene expression level was increased in late stages. The gene expression findings were correlated with morphological findings in both early and late stages of wound healing. Our findings are important for exploring the effect of centaury oil on angiogenesis via VEGFA, VEGFB, VEGFC and $F G F 2$ genes in early stages of wound healing.
\end{abstract}

Keywords : Centaury oil, Hypericum perforatum L., wound healing, angiogenesis, gene

\section{ÖZET}

Kantaron yağ1 (Hypericum perforatum' un zeytinyağı ile elde edilen ekstresi) Türkiye' de yıllardır yara tedavisinde geleneksel olarak kullanılmaktadır. Kantaron yağının yara iyileştirici özellikleri yanında ağrı kesici, enfeksiyon engelleyici özellikleri bulunmaktadır. Literatürde bu yağın yara iyileşmesine olan pozitif etkisi ile ilgili birçok çalışma vardır. Ancak literatürde şimdiye dek bu özelliklerin hangi yolaklar üzerinden olduğunu gösterir hayvan deneylerini içeren detaylı bir çalışma bulunmamaktadır. Çalışmamızda kantaron yağının yara iyileşmesi üzerine erken dönem (ilk 7 gün) ve geç dönem (ikinci 7 gün) etkisi farelerde (mus. musculus) sırt bölgesinde steril sütürler oluşturularak gösterilmiştir. Sonuçlarımıza göre, farelerde oluşturulan yara yüzeyinde morfolojik olarak kantaron yağının erken dönem kullanımda pozitif etkisi olmakta, geç dönem uygulamada bu etki görülmemektedir. Bu bulgu kantaron yağının yara iyileşmesine yara oluştuktan sonraki ilk haftada pozitif etkisi olduğu şeklinde yorumlanmıştır. Bu dönemde alınan dokulardan RT-PCR yöntemi ile anjiyogenez üzerinden yara iyileşmesinde rolü olan $V E G F A, V E G F B, V E G F C, P D G F B$ ve FGF2 genlerinin gen ekspresyon profilleri incelenmiştir. Sonuç olarak erken dönemde VEGFA, 
$V E G F B, V E G F C$ ve $F G F 2$ genlerinin gen ekspresyonları artmakta, geç dönemde bu etki yalnızca $V E G F A$ geninde saptanmaktadır. Erken ve geç dönemde bulunan gen ekspresyonu bulguları saptanan morfolojik özelliklerle korelasyon göstermektedir. Bulgular kantaron yağının erken dönem yara iyileşmesini anjiyogenezde rol oynayan $V E G F A, V E G F B, V E G F C$ ve $F G F 2$ üzerinden yaptığını göstermesi açısından önemlidir.

Anahtar sözcükler: Kantaron yağı, Hypericum perforatum, yara iyileşmesi, anjiyogenez, gen.

\section{INTRODUCTION}

Centaury oil is prepared from Hypericum perforatum with olive oil. Hypericum as a genus is mostly founded plant around the world. It is especially found on the Taurus Mountains in Turkey, beside it is naturally blossomed in many places in our country 1,2 . The plants in hypericum perforatum species use widely in therapeutic area. They inhibit microorganism propagation by the antiseptic property; inhibit inflammation by the anti-inflamatory property; stop bleeding by the vasoconstructive property and help the wound to heal faster by cell generation property. They also reduce the pain and discomfort during its usage as an extract ${ }^{3,4}$. The studies in literature about the centaury oil, there were many morphological evaluations on wound healing but there was no study about the effect mechanisms and the effected genes 5,6 . In the first part of our study, we aimed to find out the effects of centaury oil on wound healing. For this purpose we made sterile wounds on mice and applied centaury oil to find out the possible role of this extract on wound healing. So, if it is used in the first days of wound had positive effect on wound healing but if it is used subsequent days of wound had little positive effect on wound healing, not enough as early usage. This results show us that centaury oil has wound healing effect in the early phases of wound formation.

Wound healing is a regeneration and recreation process of the skin or another organ after an injury. Wound healing process has four grades; homeostasis, inflammation, proliferation and remodeling ${ }^{7}$. The most active grade is proliferation phase. This phase includes angiogenesis, collagen depositing, granulation tissue forming, epithelialization and wound contraction. During angiogenesis vascular endothelial cells forms new blood vessels. Fibroblasts growth up and contribute fibroplasias and formation of granulation tissue. Reepithelialization begins in the epidermis and the wound area begins to full with new tissue ${ }^{8}$. In the second part of our study, we investigated the possible effect of centaury oil on the genes especially active in the proliferative phase of wound healing process ${ }^{9}$. For this aim, the gene expression profiles of Vascular endothelial growth factor-A (VEGFA), VEGFB, VEGFC, Plateletderived growth factor- $B$ (PDGFB) and Fibroblast growth factor-2 $(F G F 2$ ) from the tissues of the wound areas were analyzed with Real-time Polymerase Chain Reaction (RTPCR) method. So, we found the expression levels of $V E G F A, V E G F B$, $V E B G F C$ and $F G F 2$ elevated. This results show us that the effect of centaury oil on wound healing process occurred over the genes $V E G F A, \quad V E G F B, \quad V E B G F C$ and $F G F 2$ in proliferation phase. 


\section{MATERIALS METHODS}

Preparing the extract of Hypericum perforatum with olive oil:

Hypericum perforatum was rested in the olive oil for two weeks according to the traditional methods for obtaining centaury oil ${ }^{10}$.

Preparing the animal groups: An ethic decision was obtained for our animal study in September 20, 2013(Gülhane Military Medical Academy, animal ethic committee). Twenty one mice were separated into three different groups. Seven mice (three for group A, three for group B, one for final control) were used for control group. Seven mice were used for group A ( early application-first 7 days of wound- of centuary oil). Seven mice were used for group B ( late application-second 7 days of wound- of centuary oil). In each group, sterile cuts were carried out for ensuring clean wounds. The cuts were suturised and the wounded areas were clearly dressed ${ }^{11}$. In the control group daily dressings were applied only. In group A, centaury oil was applied for the first 7 days till the sutures were picked up. In group B, centaury oil was applied for the second 7 days, after the sutures were picked up.

Investment of wound healing: The wound healing areas of the mice in the control and study groups were evaluated clinically. In this clinically evaluation, edema, hyperemia, bleeding, granulation tissue, scar uncertainty and refeathering of the wound areas were observed ${ }^{12}$.
Tissue sample preperation: In the $7^{\text {th }}$ day of study, the wound areas of three mice from control group and five mice from group A were completely taken for RNA isolation. In the $14^{\text {th }}$ day of study, the wound areas of three mice from control group and five mice from group B were completely taken for RNA isolation. At least one mouse was left alive for final comparison.

RNA isolation from tissue samples: After thawing the tissue samples taken from control group and study groups in the liquid nitrogene, RNAs were isolated according to the manufacturer company's method (NucleoSpin RNA-Machenery Nagel).

\section{Revers Transcription Polimease Chain Reaction (RT-PCR):} The obtained RNAs were converted to cDNAs by revers transcriptase by using Rt-PCR method according to the manufecturer's method (RevertAid First Strand cDNA Synthesis Kit - Life TechnologiesFermantas) ${ }^{13}$. The PCR conditions were $42^{\circ} 60^{\prime}, 70^{\circ} 5^{\prime}$ and the final volum was $20 \mu \mathrm{l}$ for each run.

Real Time Polimease Chain Reaction (RT-PCR): The cDNAs were used as master for RT-PCR. In the procedure, the primers of $V E G F A$, $V E G F B, V E G F C, P D G F B$ and $F G F 2$ were used. Primer lists were taken from Primer Bank (http://pga.mgh.harvard.edu/primerb ank). As house-keeping gene, $\beta$-actin was used. Each reaction was performed as $20 \mu \mathrm{l}$ final 
concantration $(10 \mu 1$ Mastermix, $5 \mu 1$ DNA, $0,5 \mu \mathrm{l}$ primer, $4 \mu \mathrm{l}$ $\left.\mathrm{H}_{2} \mathrm{O}\right)\left(\mathrm{SYBR}{ }^{\circledR}\right.$ Green PCR Master Mix- Roche Life Science) . RT-PCR conditions were $59^{\circ}$ for 45 cycles. The gene expression alterations were evaluatedwith relative quantification method with Roche Applied Sciences LightCycler 1.5 software program.

Statistical Analyses: Chi-Square test for wound healing evaluation and Student T-Test for RT-PCR evaluation were used.

\section{RESULTS}

Edema, hyperemia, bleeding, granulation tissue, scar uncertainty and refeathering of the wound areas were evaluated macroscopically in each group (Table 1). Due to the results, only granulation tissue formation was observed in control group. In group A and group B beside granulation tissue, scar uncertainty and refeathering were observed either. This finding shows us, the wound healing process was faster in group $\mathrm{A}$ and $\mathrm{B}$ due to the control group. The wound healing process was photographed immediately, at $7^{\text {th }}$ and $14^{\text {th }}$ days and according to the photos, the wound closures of group A (Figure $2 b$ and 2c) were much better and regular according to control group (Figure 1b and 1c) and group B (Figure $3 b$ and $3 c$ ). This finding represents us that centaury oil effects wound healing process especially in early phase. In late phase centaury oil application, the results in group B (Figure $2 b$ and $2 c$ ) were found as similar in control group (Figure $1 \mathrm{~b}$ and 1c). According to this result, centaury oil has no effect on wound healing in late phase.

Table 1. Clinical evaluation of wound healing.

\begin{tabular}{|l|l|l|l|l|}
\hline \multirow{2}{*}{ GROUPS } & \multirow{2}{*}{ Wound Healing Properties } & \multicolumn{3}{|l|}{ Days } \\
\cline { 2 - 5 } & & 0. day & 7.day & 14. day \\
\hline Control Group & Edema & +++ & + & - \\
\cline { 2 - 5 } & Hiperemia & +++ & + & - \\
\cline { 2 - 5 } & Bleeding & +++ & - & - \\
\cline { 2 - 5 } & Granulationtissue & - & + & +++ \\
\cline { 2 - 5 } & Scar uncertainty & - & + & - \\
\cline { 2 - 5 } & Refeatering & & & - \\
\hline \multirow{5}{*}{ Group A } & Edema & +++ & + & - \\
\cline { 2 - 5 } & Hiperemia & +++ & ++ & - \\
\cline { 2 - 5 } & Bleeding & +++ & - & - \\
\cline { 2 - 5 } & Granulationtissue & - & + & +++ \\
\cline { 2 - 5 } & Scar uncertainty & - & +++ & +++ \\
\cline { 2 - 5 } & Refeatering & & & +++ \\
\hline \multirow{5}{*}{ Group B } & Edema & +++ & + & - \\
\cline { 2 - 5 } & Hiperemia & +++ & - & - \\
\cline { 2 - 5 } & Bleeding & +++ & - & - \\
\cline { 2 - 5 } & Granulationtissue & - & + & +++ \\
\cline { 2 - 5 } & Scar uncertainty & - & ++ & + \\
\cline { 2 - 5 } & Refeatering & & & ++ \\
\hline
\end{tabular}


$\mathbf{a}$

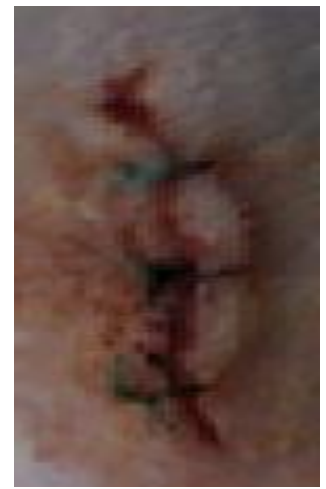

b

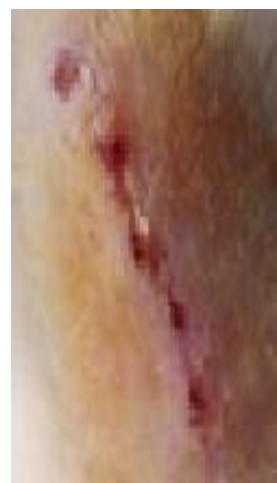

c

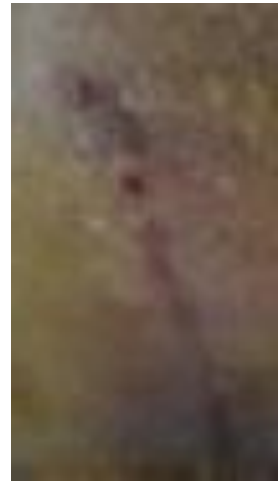

Figure 1. Photos from wound areas of control group (photos were taken on the $1^{\text {st }}$ $7^{\text {th }}-14^{\text {th }}$ days respectively).

a

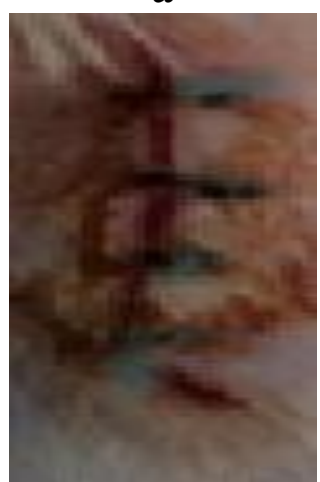

b

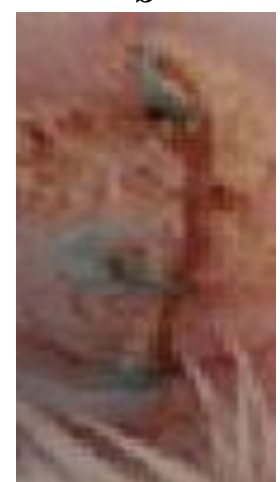

c

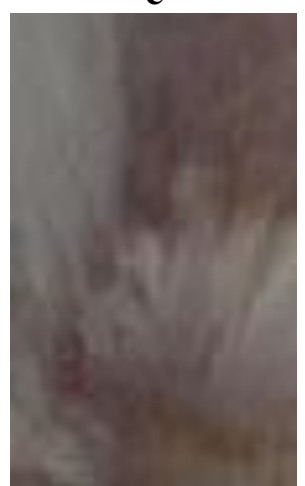

Figure 2. Photos from wound areas of group A (photos were taken on the $1^{\text {st }}-7^{\text {th }}$ $14^{\text {th }}$ days respectively)

a

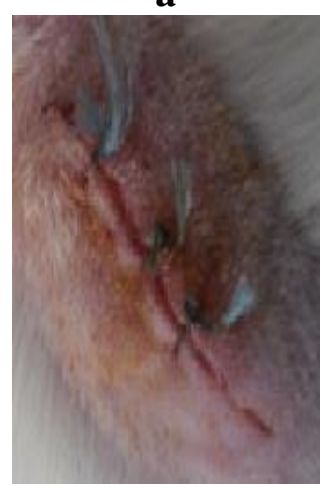

b

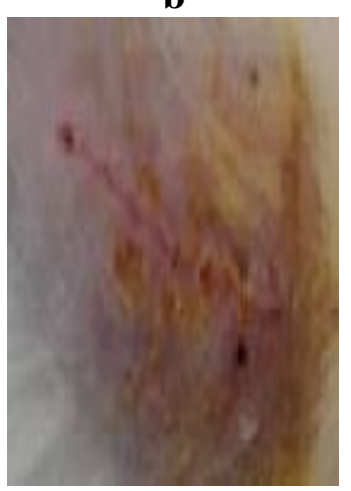

c

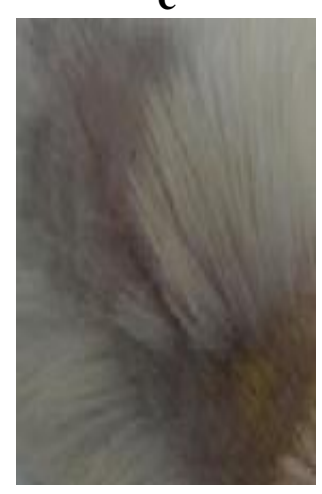

Figure 3. Photos from wound areas of group B (photos were taken on the $1^{\text {st }}-7^{\text {th }}$ $14^{\text {th }}$ days respectively). 
The results of molecular evaluations were encourages the clinical results (Table 2). In our study the gene expression levels of VEGFA were found approximately 7 fold increased $(\mathrm{p}<0.05)$ according to control group whereas approximately 4 fold increased in group B $(\mathrm{p}<0.05)$. $V E G F B$ gene expression results were found approximately 4 fold increased in group $\mathrm{A}(\mathrm{p}<0.05)$, approximately 10 fold decreased in group $B$ $(\mathrm{p}<0.05) . V E G F C$ gene expression levels were found approximately 5 fold increased in group A $(\mathrm{p}<0.05)$, whereas approximately 7 fold decreased in group B $(\mathrm{p}<0.05)$. Interestingly, the expression levels of
$P D G F B$ gene were found very low in group A (approximately 100 fold decreased $)(p<0.05)$ and low in group B (approximately 10 fold decreased) $(\mathrm{p}<0.05)$. The expression levels of FGF2 gene were found approximately 70 fold increased in group A $\quad(\mathrm{p}<0.05) \quad$ whereas approximately 10 fold decreased in group B $(\mathrm{p}<0.05) \quad($ Table 2). So, centaury oil affects on wound healing in the first 7 days via $V E G F A$, $V E G F B, V E G F C, P D G F B$ and $F G F 2$ genes. Due to our results, the expression levels of gene which has mitogenic effect on cells were extremely low in study groups according to control group.

Table 2. The gene expression findings.

\begin{tabular}{|l|l|l|l|l|l|l|}
\hline & $\begin{array}{c}\text { Control } \\
\text { group for } \\
\text { Group A }\end{array}$ & Group A & $\begin{array}{c}\text { P } \\
\text { value }\end{array}$ & $\begin{array}{c}\text { Control } \\
\text { group for } \\
\text { Group B }\end{array}$ & Group B & $\begin{array}{c}\text { P } \\
\text { value }\end{array}$ \\
\hline VEGFA & $0,003 \pm 0,00$ & $0,022 \pm 0,00$ & 0,01 & $0,023 \pm 0,01$ & $0,103 \pm 0,26$ & 0,02 \\
\hline VEGFB & $0,070 \pm 0,02$ & $0,305 \pm 0,28$ & 0,01 & $0,556 \pm 0,29$ & $0,057 \pm 0,057$ & $<0,01$ \\
\hline VEGFC & $0,433 \pm 0,19$ & $2,195 \pm 1,81$ & $<0,01$ & $4,896 \pm 0,48$ & $0,667 \pm 1,13$ & $<0,01$ \\
\hline $\boldsymbol{F G F 2}$ & $0,000 \pm 0$ & $0,007 \pm 0,01$ & 0,25 & $0,010 \pm 0,01$ & $0,001 \pm 0,00$ & 0,11 \\
\hline $\boldsymbol{P D G F B}$ & $0,009 \pm 0,00$ & $0,000 \pm 0$ & 0,01 & $0,017 \pm 0,01$ & $0,000 \pm 0,00$ & $<0,01$ \\
\hline
\end{tabular}

\section{CONCLUSIONS}

Wound healing is an intricate process where the skin or other body tissue repairs itself after injury. This process is divided into predictable phases: blood clotting (hemostasis), inflammation, the growth of new tissue (proliferation), and the remodeling of tissue (maturation) ${ }^{7}$. In hemostasis phase, platelets in the blood begin to stick to the injured site, within the first few minutes of injury. Platelets change into an amorphous shape, more suitable for clotting, and they release chemical signals to promote clotting. This results in the activation of fibrin, which forms a mesh and acts as "glue" to bind platelets to each other for making a clot 14,15 . In inflammation phase, damaged and dead cells are cleared out, along with bacteria and other pathogens or debris. This happens through the process of phagocytosis. Platelet-derived growth factors are released into the wound that cause the migration and division of cells during the proliferative phase. In proliferation phase, angiogenesis, collagen deposition, granulation tissue formation, epithelialization, and wound contraction occur. In angiogenesis phase, vascular endothelial cells form new blood vessels. In this phase, unneeded cells 
undergo apoptosis. In remodeling phase, collagen is realigned along tension lines, and cells that are no longer needed are removed by programmed cell death, or apoptosis 16.

Centaury oil been intensively investigated for its antidepressive activity, but dermatological applications also have a long tradition. Topical centuary oil preparations such as oils or tinctures are used for the treatment of minor wounds and burns, sunburns, abrasions, bruises, contusions, ulcers, myalgia, and many others ${ }^{17}$. The ingredients; naphthodianthrones (e.g., hypericin) and phloroglucinols (e.g., hyperforin) have interesting pharmacological profiles, including antioxidant, anti-inflammatory, anticancer, and antimicrobial activities. In addition, hyperforin stimulates growth and differentiation of keratinocytes, and hypericin is a photo sensitizer which can be used for selective treatment of nonmelanoma skin cancer. Sporadic trials have been conducted in wound healing, atopic dermatitis, psoriasis, and herpes simplex infections ${ }^{1}$. Although there are many studies about the topical effects of centaury oil in literature, there is no study about the cellular effects of this extract. The clinical results show the positive effects on wound healing but there is no study about the molecular effects of this extract around the wounded area. In our study, we investigated the topical effects of centaury oil on wounded area and also we studied the molecular effects of this extract on the genes VEGFA, VEGFB, VEBGFC, $P D G F B$ and $F G F 2$.
As clinical findings, edema, hyperemia, bleeding, granulation tissue, scar uncertainty and refeathering of the wound areas were evaluated macroscopically in each group (Table 1). Only granulation tissue formation was observed in control group. In group A and group $\mathrm{B}$ beside granulation tissue, scar uncertainty and refeathering were observed either. This finding shows us, the wound healing process was faster in group A and B due to the control group.

In a recent manuscript, Toledo-Piza et all reported that cell proliferation increases in control group in the $5^{\text {th }}$ day. Remodeling begins in the $6^{\text {th }}$ day. Granulation and scar tissues occurs in $13^{\text {th }}$ day ${ }^{12}$. Süntar et all applied centaury oil only in the first seven days after the surgery (proliferation phase) ${ }^{2}$. In our study, centaury oil was applied in active phase of wound (in the first seven days after the surgery) (proliferation phase) and in late phase of wound (in the second seven days after the surgery) (remodeling phase). In group A, all of the evaluating properties were better than control group and group B. So we can say that early usage of centaury oil (first 7 days of wound) had positive effect on wound healing. So, we obtained similar results due to literature findings ${ }^{5}$. In group B, only granulation tissue, scar uncertainty and refeathering properties were a little different from control group. We can say late usage of centaury oil (second 7 days of wound) had only little positive effect on wound healing, not enough as early usage. 
Wound healing is a complex and sensitive process. In proliferative phase of wound healing, $V E G F$, $P D G F, \quad F G F$, epidermal growth factor-EGF, and transforming growth factor-TGF gene families have active roles ${ }^{7}$. Deonarine et all were reported that inflammatory genes expressed firstly in wound healing. Angiogenesis-related and proof reading-related genes expressed later 8,9 . In our study, the molecular mechanisms were analyzed in centaury oil application on wound healing process for the first time in literature. Especially angiogenesisrelated genes were analyzed for the possible roles in wound healing with centaury oil. Due to RT-PCR results, the wound healing effect of the early usage of centaury oil materialized via $V E G F A, \quad V E G F B, \quad V E B G F C$ and $F G F 2$ genes (Table 2). In our results, in late phase wound healing only

\section{REFERENCES}

1. Wölfle U, Seelinger G, Schempp CM. Topical application of St. John's wort (Hypericum perforatum). Planta Med 2014; 80: 109-20.

2. Suntar IP, Akkol EK, Yilmazer D, Baykal T, Kirmizibekmez H, Alper $\mathrm{M}$, Yeşilada E. Investigations on the in vivo wound healing potential of Hypericum perforatum L. J Ethnopharmacol 2010; 127: 468-77.

3. Saddiqe Z, Naeem I, Maimoona A. A review of the antibacterial activity of Hypericum perforatum L. J Ethnopharmacol 2010; 131: 511-21.

4. Suntar I, Akkol EK, Keleş H, Oktem A, Başer KH, Yeşilada E. A novel wound healing ointment: a formulation of Hypericum perforatum oil and sage and oregano essential oils based on traditional
VEGFA gene expression was high (Table 2). Having high VEGFA expression levels in early and late phases represent the role of VEGFA in wound healing in all stages. The low expression levels of $P D G F B$ gene show us that centaury oil had no mitogenic effect during wound healing ${ }^{17}$. This finding represents that centaury oil has no positive effect on cell proliferation on wound healing process.

As a result, we found the positive effect of centaury oil on wound healing if it is used in the first 7 days of the wound. Beside this, it is observed that this extract has positive effects on the gene expression levels of VEGF-A, VEGF-B, VEGF-C and $F G F-2$ especially in the first 7 days of the wound. Due to these results, we can say that centaury oil has positive healing effect via these genes.

Turkish knowledge. J Ethnopharmacol 2011; 134: 89-96.

5. Samadi S, Khadivzadeh T, Emami A, Moosavi NS, Tafaghodi M, Behnam HR. The effect of Hypericum perforatum on the wound healing and scar of cesarean. J Altern Complement Med 2010; 16: 113-7.

6. Läuchli S, Hafner J, Wehrmann C, French LE, Hunziker T. Post-surgical scalp wounds with exposed bone treated with a plant-derived wound therapeutic. J Wound Care 2012; 21: 232-3.

7. Lawrence WT, Diegelmann RF. Growth factors in wound healing. Clin Dermatol 1994; 12: 157-69.

8. Ciğer S. Yara İyileşmesinde Büyüme Faktörleri, İ.Ü.Cerrahpaşa Tıp Fakültesi Sürekli Tıp Eğitimi Ciğer S. Yara İyileşmesinde Büyüme Faktörleri, İ.Ü.Cerrahpaşa Tip 
Fakültesi Sürekli Tıp Eğitimi Etkinlikleri, Cilt Hastalıkları ve Yara Bakımı Sempozyumu, 18-19 Ekim 2001, İstanbul.

9. Deonarine K, Panelli MC, Stashower ME, Jin P, Smith K, Slade HB, Norwood C, Wang E, Marincola FM, Stroncek DF. Gene expression profiling of cutaneous wound healing. J Transl Med 2007; 5: 11.

10.Ong ES. Extraction methods and chemical standardization of botanicals and herbal preparations. J Chromatogr B Analyt Technol Biomed Life Sci 2004; 812: 23-33.

11.Çoban ZD. Fare Gelişiminde Rolü Olan Nöronal Faktörlerin Gen Ekspresyon Düzeylerinin Belirlenmesi. Doktora Tezi, 2014.

12.Toledo-Piza AR, Maria DA. Healing Process in Mice Model of Surgical Wounds Enhanced by Phyllocaulis boraceiensis Mucus. Adv Skin Wound Care 2014; 27: 538-47.

13.Gulsen MR, Uzunay NS, Fermanl1 O, Coban ZD, Oztürk D, Hamidi M, Avcu F, Guran S. Anti-angiogenic Role of Ankaferd on Chick Chorioallontoic Membrane Model. Gülhane Medical Journal (In press).

14.Rieger S, Zhao H, Martin P, Abe K, Lisse TS. The role of nuclear hormone receptors in cutaneous wound repair. Cell biochemistry and function 2014; 33: 1-13.

15.Versteeg HH, Heemskerk JWM, Levi M, Reitsma PH. New Fundamentals in Hemostasis. Physiological Reviews 2013; 93: 327-58.

16.Midwood KS, Williams LV, Schwarzbauer JE. Tissue repair and the dynamics of the extracellular matrix. The International Journal of Biochemistry \& Cell Biology 2004; 36: 1031-7.
17.Zhao Y, Lv W, Piao H, Chu X, Wang $\mathrm{H}$. Role of platelet-derived growth factor-BB (PDGF-BB) in human pulmonary artery smooth muscle cell proliferation. J Recept Signal Transduct Res 2014; 34: 254-60. 